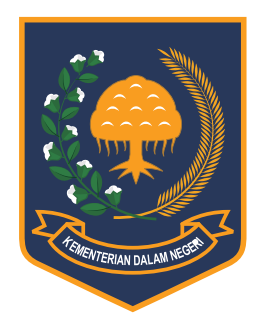

JURNAL BINA PRAJA

e-ISSN: 2503-3360 | p-ISSN: 2085-4323

Accreditation Number

21/E/KPT/2018

http://jurnal.kemendagri.go.id/index.php/jbp/index

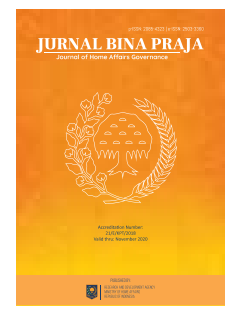

\title{
Performance Analysis of Depok City Health Office in Supporting Child-Friendly City
}

\author{
Vishnu Juwono*, ${ }^{*}$ Bintang Cynthia Damara ${ }^{2}$ \\ ${ }^{1,2}$ Faculty of Administrative Science Universitas Indonesia \\ Prof. Dr. Mr. Prajudi Atmosudirdjo Building, Level 2, FIA UI \\ Depok, Indonesia 16424
}

Received: 24 June 2019; Accepted: 27 March 2020; Published online: 28 May 2020

DOI: $10.21787 / \mathrm{jbp} .12 .2020 .1-10$

\begin{abstract}
The government has to pay attention to the fulfillment of children's rights because later, they will determine the fate of the nation and state in the future. One of the things that can be done by the Government is by organizing a Child-Friendly City. One significant cluster related to the implementation of a Child-Friendly City is a cluster of essential health and well- being. The Depok City Government, through the Health Office, has made various efforts to support the realization of a Child-Friendly City in the health sector. Depok has the third-highest Human Development Index in West Java, but it turns out there are still toddlers who are malnourished to cases of infant mortality. In 2013, the number of undernourished toddlers was 87 children, then in the following year it decreased by 75 children and in 2015 and 2016 cases of malnourished infants increased by 77 and 85 toddlers. While in 2017, the number declined slightly from the previous year, namely 83 toddlers experiencing poor nutrition. The research method used in this study is qualitative with a post-positivist approach. There are eight resource persons, not just from Depok City's office but also an NGO activist and academics as a resource person for primary data. As for secondary data, including academic journal articles, reports, and mass media publications. Based on the results of the study, through the target approach in measuring organizational effectiveness by S. B Lubis and Martani Huseini, the Health Office has exceeded the goals set out in the Medium-Term Development Plan. The achievement of these targets is inseparable from the factors that influence the organization in carrying out its performance. Based on McKinsey's theory, seven factors influence the Health Office to support ChildFriendly Cities, two of which have gone well, namely, the leader who motivate their subordinates and the budget and technology that supports the implementation of Child-Friendly Cities. But the other five factors have not gone well; namely, the Health Office does not yet have a specific strategy related to Child-Friendly Cities. This includes coordination that has not run optimally, lack of Human Resources both in terms of numbers and competencies, and the absence of organizational culture specifically for the Office of Health in carrying out its functions. Therefore, the Health Office needs to make improvements from the factors that have not gone well so that Depok City can be a Child- Friendly City.
\end{abstract}

Keywords: Child-Friendly City, Health Office, Depok City, Children’s Nutritional Status, 7s Model

\section{INTRODUCTION}

As the nation's next-generation, children deserve special attention from the government. If children are educated and nurtured early on, their health and well-being are considered, the environment is safe and comfortable. They will grow up to be intelligent adults and can play a role in the progress of the nation and the State. Children are the nation's capital to continue the development of a sustainable country. Fulfillment of children's rights is a fundamental issue in the international world until States Parties / Signatories to the United Nations Convention on the Rights of the Child declare to guarantee and respect every child's rights without discrimination in any form (Sedletzki, 2011; UNICEF, 2017).

The government must place children in the main focus through development so that a childfriendly environment can be realized (Sedletzki, 2011; UNICEF, 2017). One of the things that can be done by the Government is to implement a ChildFriendly City. Of the several clusters and indicators

\footnotetext{
* Corresponding Author

Phone : +62816943804

Email : vjuwono@ui.ac.id
} 
found in Child-Friendly Cities, health is an important aspect to be considered (Bishop \& Corkery, 2017). Health is one of the most basic needs of society. The level of public health dramatically influences the level of welfare of the community itself. In the vicious circle of poverty, the three principal axes that cause people to become poor are low levels of health, low income, and low levels of education. Development in the health sector is an initial step for equitable welfare improvement. It fits for the government to prosper its people through a series of actions and innovations in the health sector. Therefore, optimizing the role of the government in the health sector is very important for the welfare of society at large.

The current academic literature in the childfriendly city is mostly focusing on urban cities in developed countries (Gill, 2019; McAllister, 2008; Monaghan, 2019; Nam \& Nam, 2018; Riggio, 2002) while other literature emphasizes on how to build a child-friendly city (Bishop \& Corkery, 2017; Chan et al., 2016; Cushing, 2016; Goldfeld et al., 2019; van Vliet \& Karsten, 2015). Meanwhile, policy implementation focus literature in Indonesia is scarce, such as Febriyanti \& Juwono (2017) as well as Hadi \& Juwono (2019). Thus, these articles contribute to the literature gaps in the child-friendly city in developing countries, which is Depok City in Indonesia.

One of the cities in Indonesia that implemented the Child-Friendly City program was Depok City. The program is contained in the Depok City Regional Regulation Number 15 of 2013 concerning the Implementation of a Child-Friendly City. The city of Depok has the third-highest Score Human Development Index in West Java, but it turns out there are still toddlers who are malnourished to cases of infant mortality. In 2013, the number of undernourished toddlers was 87 children, then in the following year, decreased by 75 children, and in 2015 and 2016, malnutrition cases increased by 77 and 85 toddlers. While in 2017, the number dropped slightly from the previous year, namely 83 underfives experiencing poor nutrition (KPP\&PA \& BPS, 2015). Even though nutritional status is one of the indicators used to determine health status, where a person's dietary conditions are strictly related to health problems, nutritional requirements can also directly cause health problems. Monitoring is carried out on the nutritional status of infants and toddlers because this period is a golden period for the development of intelligence and physical growth (Dinas Kesehatan Kota Depok, 2017).

The case of malnutrition that befell Depok City is an indication that the Government has not performed. There needs to be a commitment from all members in organizational units/institutions in creating optimal service so that each child has their right to live in prosperity. The performance of the Depok City Health Office needs to be improved so that existing health problems can decrease.

Success or failure of an organization to be measured by several approaches to organizational effectiveness, according to Lubis \& Huseini (2009, p. 97). It states that a goal approach can measure organizational success, system source approach, internal process approach, and a combined approach. The measurement is consisting of different parts, starting from the input, then processing to produce output.

Each organizational effectiveness approach refers to the processes within the organization, namely input, process, and output. In the context of a Child-Friendly City, the output or target is a main concern because to achieve success in becoming a Child-Friendly City, the Government needs to reach or even exceed a set number of goals. If the Depok City Health Office wants to support the realization of a Child-Friendly City, then several achievement targets must be achieved. Therefore, to assess the success or failure of Depok City Health Service, their performance needs to be measured by a goal approach.

In carrying out its role to support ChildFriendly Cities, Depok City Health Office certainly faces various challenges and obstacles that come from both inside and outside the organization. These challenges and obstacles comefrom factors that affect organizational performance. This article analyze factors that affect organizational performance, and use the 7 (Seven) S model proposed by McKinsey. The 7 (Seven) $S$ is a management model to see how effective the organization is in achieving its desired goals. In the $7 \mathrm{~S}$ method, there are seven specific factors to analyze what affects the organization in achieving its objectives. The 7S Model is divided into two types, the first is hardware consisting of strategy and structure, and the second is software consisting of style, system, staff, skills, and shared values.

\section{METHOD}

In this study, the authors used qualitative research methods. The researcher interviewed by asking several questions according to the indicators observed to understand the main causes. The research approach used in this study is postpositivism. This type of research uses a descriptive kind of research. This descriptive study has the purpose of describing and interpreting situations and conditions according to reality (Creswell, 
2008). In this case, the research aims to describe the performance of the Depok City Health Service to Support Child-Friendly Cities and the factors that influence the performance of the Depok City Health Office. This study is categorized as pure research. This study was also used to determine the efforts made by the Depok City Health Office to Support Child-Friendly Cities and the factors that influenced the performance of the Depok City Health Service to realize Depok City as Eligible for Children. Data collection techniques in this study are using indepth interview and data collection, which are categorize into two data, namely primary and secondary data. There are eight resource people for the interview, not just Depok city's officials but also an NGO activist and academics for primary data. Primary data obtained through interviews and secondary data collected based on literature studies. The timeline of the research is within three months, namely September to December 2018. Within that period, it was considered sufficient for researchers to obtain information related to the role of the Depok City Health Office to Support a ChildFriendly City.

\section{RESULTS AND DISCUSSION}

\section{A. Performance of Depok City Health Office in Supporting Child-Friendly Cities}

The performance carried out by the Depok City Health Office in supporting Child-Friendly Cities can be assessed from the effectiveness of achieving their objectives. Based on the organization effectiveness measurement theory presented by Lubis \& Huseini (2009), an organization can be assessed for its performance through an assessment of the output or achievement of previously determined targets. The Depok City Health Office has several goals that must be achieved in carrying out its functions and duties. One of the goals that must be made by the Depok City Health Office is related to child nutrition. According to the Depok City Health Office, nutritional status is one indicator that can be used to determine health status because it is closely related to health problems that occur.

Nutritional problems in infants are related to the baby's weight at birth. Percentage of Babies Low Birth Weight (LBW) in Depok City 2014-2017 tends to increase every year. Based on the 2013 report, there were 501 LBWs (1.2\%); in 2014, LBW cases were $442(0.9 \%)$ out of 46,679 newborns who were weighed. In 2015 the number of newborns weighed was 40,186, with a total LBW of $393(1.0 \%)$. Then in 2016, the number of LBWs was 411 (1.0\%) out of 41,817 newborns weighed (Dinas Kesehatan Kota Depok, 2018). However, the percentage of Depok City BBLR in 2014-2017 still exceeds the target set by the West Java Health Office in the 2016-2019 Medium Term Development Plan, which is $8 \%$. Although the LBW targets or targets in $2017 \mathrm{far}$ exceed the goals set, the Depok City Health Office still needs to carry out intensive supervision given the trend of an increase in such cases.

In addition to infant nutrition, toddler nutrition must also be a concern because there are still toddlers with poor nutritional status. In 2013, there were 87 malnourished children $(0.08 \%)$, then in the following year 2014 decreased by $75(0.06 \%)$ under-fives, and in 2015, and 2016 malnutrition cases increased by $77(0.06 \%)$ and $85(0.06 \%)$ cases. While in 2017, the number decreased slightly from the previous year, namely 83 under-fives experiencing poor nutrition (Dinas Kesehatan Kota Depok, 2018). The number of toddlers with poor nutritional status in Depok has fluctuated from year to year, but from 2014 to 2016, it has continued to increase, before finally falling by two figures in 2017. The national target for the percentage of malnourished children is $15 \%$ (Kementerian Kesehatan, 2018). Therefore, it can be assessed that Depok City far exceeded the goals specified in the 2016-2019 Medium Term Development Plan.

In the Depok City Medium Term Development Plan, Child-Friendly Puskesmas is targeted to reach $40 \%$ of all Puskesmas (health center). Until the end of 2018, the realization was 14 Puskesmas from 35 Puskesmas listed on the official website or precisely $40 \%$ according to the target Medium Term Development Plan. In Depok City Medium Term Development Plan 2006-2025, it did not specify in detail what aspects need to be fulfilled in the implementation of Child-Friendly Puskesmas. So, the achievement target of the Depok City Health Office regarding the application of a Child-Friendly City is based on the minimum standards set by the Ministry of Women's Empowerment and Child Protection. Child-Friendly Puskesmas has become one of the essential indicators in Child-Friendly Cities, and Depok City has succeeded in meeting the target percentage of Child-Friendly Puskesmas in 2018. In the next three years, in 2021, the implementation of Child-Friendly Health Centers must match 100\% or means that all Puskesmas in Depok must hold the program. Therefore, the Health Office must continue to improve its services and encourage health centers that have not implemented the ChildFriendly Community Health Center program so that the target in 2021 can be fulfilled. 


\section{B. Factors Affecting the Performance of the Depok City Health Service in Supporting a Child-Friendly City}

\section{1) Strategy}

An essential strategy for each organization to be able to implement a program smoothly. Depok City Health Office has its policy in the process of organizing Child-Friendly Cities, specifically the Family and Nutrition Health Section. It has an essential role in fulfilling the number 3 (three) ChildFriendly Cities, namely essential health and child welfare. There are two strategies implemented by the Office of Health, namely training officers on the Convention on the Rights of the Child and holding workshops on the socialization of Child-Friendly Health Centers.

For the second strategy, it is namely conducting workshops related to the socialization of ChildFriendly Health Centers for all stakeholders to be aware of the existence of Child-Friendly Puskesmas so that stakeholders can be involved. Fifteen indicators must be met in the implementation of a Child-Friendly City. The Health Office only monitors for six months to the Puskesmas, and in the course of 6 months, there are some changes related to facilities and services provided to patients or children. One of which is the absence of children's playgrounds, even though the availability of pedestal is in children's playground is one indicator in the service of Child-Friendly Puskesmas. The first and second strategies have the same goal, namely, to raise awareness of both government officials and stakeholders on a Child-Friendly City. The first strategy is by training these stakeholders about the Convention on the Rights of the Child so that the services provided to children are by what is the right of children. Training on the Convention on the Rights of the Child is an indicator in a ChildFriendly Community Health Center. The type of training in the Convention on the Rights of the Child itself is the presentation of the meaning of program implementation that supports the fulfillment of children's rights and understanding of the CRC itself. The second strategy is by holding workshops, so it is hoped that various groups and layers can widely know Child-Friendly Health Centers of society. If packaged attractively, the trainees may enthusiastically follow the course of the training or workshop. The workshop was considered as a form of community involvement carried out by the Health Office. Still, it turned out that the workshop was only limited to the delivery of information or one-way socialization. The Depok City Health Office also has its strategy for dealing with labor problems at the Puskesmas. The lack of human resources will certainly have implications for the optimization of services provided to children because the solution to the utilization of authority for UPT Puskesmas is to contract non-PNS personnel. Puskesmas in Depok have implemented PK BLUD (Regional Public Service Agency Financial Pattern) so that they have the authority to allocate their funds to support their services with a percentage of $60 \%$ for operations and $40 \%$ returned for services. Fulfillment of personnel at the Puskesmas is closely related to the operational services provided to children as patients. If the number of personnel is not sufficient, the service delivery will not be optimal because existing HR can experience overwork. Therefore, the strategy of recruiting non-contracted employees is one of the appropriate measures because by hiring new employees, the child patients at the Puskesmas can be handled quickly. There are still nutritional problems in Depok City, both malnutrition and low birth weight, and this is also related to the health services received. If the amount of energy needed is sufficient, the nutritional problems should decrease because the officers who are obliged to handle the issues are available and can carry out their duties. However, this strategy must also be adequately considered, through job analysis and workload analysis so that the contracted employee is in-line with the organizational needs. By recruiting new employees means the Community Health Center User of Public Service Agency (PPK BLUD) uses his income funds to pay the salaries of non-contracted employees. Limited income for the PPK BLUD Puskesmas, should also be taken into consideration in recruiting non-contract employees because employees must still be paid their salary even though the number of patients is down.

\section{2) Structure}

In an organization, an organizational structure is created to map the clarity of the position of each position. Transparency can also facilitate the course of coordination so that every work done by each to reach one goal. Effective coordination is needed so that all activities can run optimally. Coordination within the Depok City Health Office is the main challenge in realizing a Child-Friendly City. ChildFriendly City is a cross-sectoral program, meaning that many parties are involved in its implementation. It requires good coordination so that a Child-Friendly City can be realized due to this fragmentation. Five clusters must be fulfilled in achieving Child-Friendly Cities, namely Civil Rights and Freedom, Family Environment and Alternative Care, Basic Health and Well-Being, Education, Utilization of Leisure and Cultural Activities, Special Protection of Child Health 
Rights, so that each involved SKPD (Regional Work Unit) must run their respective programs if they want to realize a Child-Friendly City (Frieden, 2013). Not only between Depok City Health Office but also within the Health Office itself consists of many sections or sections related to the implementation of a Child-Friendly City. Strengthening is needed to coordinate all activities carried out by the Health Office to realize one goal, which is a Child-Friendly City. Coordination in the context of Child-Friendly City is critical to do well because many elements are involved in achieving the program. In the Health Office itself, there are many sections or related sections to support the Depok City Health Office in the framework of the Child-Friendly City. Not only internal organizations, but the Health Office must also coordinate with other related agencies and communities, NGOs, and all stakeholders. If it is perceived as an obstacle, then coordination needs to be adequately addressed so that everything that is done can be aligned with the stated goals.

The lack of coordination between sectors also has an impact on not achieving the training needs of the Depok City Health Office. Not completing the necessary training for health and non-health workers at the Health Office is a result of not coordinating with BPKSDM as the training provider. The Regulations and Health Workers Section should coordinate by submitting information to BPKSDM regarding the training needed and how many employees lack the training. There is no coordination related to the training that should be held for both health and non-health workers under the Health Office by the Regulations and Health Workers Section. In the end, BKPSDM (Human Resources Agency and Human Resources Development) organizes training without considering the needs of employees at the Health Office. The training held by BKPSDM will be useless because it is not on target; even the quota provided is not by the number of employees who need training. The budget allocated for the training is wasted because employees who need training are, in fact, under the quota amount.

Regarding Child-Friendly Puskesmas as part of the implementation of Child-Friendly Cities, health workers must have sufficient training to handle children so that they can be referred to as Child-Friendly Puskesmas. Therefore, essential coordination is to be carried out by the Regulation and Health Section with each section in the Health Office so that training needs can be achieved. The training itself is a significant activity, especially for health workers, so that the services provided to children can be carried out more optimally. If health workers get the training needed, then health workers will be more capable of carrying out their profession in person. These various child health problems in Depok certainly need qualified performance from health workers so that every child who is sick and needs care or service can be appropriately handled by skilled health personnel.

\section{3) Style}

The leadership style of a leader or the way a leader affects his subordinates will also change how his aides work to achieve the set targets. Depok City Health Office is headed by a Head of Service that has performed well. One of which is related to the implementation of Child-Friendly Cities, namely by motivating their subordinates to set targets in the indicators of a Child-Friendly City, can be achieved, and programs that support a Child-Friendly City can run well. The Depok City Health Office has just undergone the replacement of the Head of Department in September 2018. Even though there was a change in leadership, the Head of the Health Service has a positive leadership style. Giving motivation by the Head of Service to his subordinates is usually carried out during the morning rally, coordination meeting, briefing, or even deliver directly to the employee. Not only motivation, but even the Head of Depok City Health Office also assisted his subordinates. All innovations carried out by the Health Service are also at the encouragement of the Head of Service.

Motivation from leaders is needed because there are still many programs that have not been achieved by the Depok City Health Office. Moreover, Depok City is planned to be a Child-Friendly City in 2021, where all programs implemented, and all existing facilities must support to be suitable for children. Therefore, Depok City Health Service must immediately accelerate their work so that the ideals of Depok City become a Child-Friendly City in 2021 is not hampered. Motivation as an encouragement for employees so that their performance focuses on one goal, namely, to realize a Child-Friendly City. The Depok City Health Office is headed by a Head of Service who is very motivating to his subordinates, and this should be an encouragement for each employee to carry out their respective functions. When viewed from the achievement target of the Depok City Health Office related to malnutrition, the percentage of Depok City itself far exceeds the aim set in the West Java Health Office Medium Term Development Plan.

\section{4) System}

\section{a) Adequate Budget \\ The implementation of a Child- Friendly City in Depok City certainly}


requires a budget to support various programs or facilities that support the welfare of children. The budget owned by the Depok City Health Office to organize a Child-Friendly City comes from the Regional Budget. Especially for the implementation of the Child-Friendly Puskesmas program, the Family and Nutrition Health Section is a section that is given a budget to support the ChildFriendly Community Health Center program. The budget for implementing the Child-Friendly City at the Health Office is given explicitly to the Family Health Section. In addition to the development of Child-Friendly Puskesmas, the budget provided to the Health Office is also allocated to routine activities such as counseling the Convention on the Rights of the Child to health and non-health workers. This is done because one of the conditions of a Child-Friendly Health Center is that there are at least two workers in the Puskesmas who have been trained in the Convention on the Rights of the Child. However, this budget only covered a small fraction of the total operational costs that are needed.

Some Puskesmas have BLUD Regional Public Service Agency) status. For Puskesmas that have BLUD, the status they are permitted to carry out financial management independently and do not depend on the Health Office anymore.

The problem that arises related to BLUDs is that BLUDs do not always generate profits. If the Puskesmas gets a profit, then they can use it to recruit employees if the funds are sufficient, because they also have to be able to consider whether by hiring new employees, they can pay employee salaries by the contract. Because back in providing health services by the Puskesmas does not always generate profits.

So, with authority given by the Government to the Puskesmas to manage their income, it is not necessarily secure. Because the primary purpose of the Puskesmas is to provide services to the community by not prioritizing benefits or Puskesmas whose primary purpose is for social as stated in Ministerial Regulation Domestic Affairs Number 61 the Year 2007. So Puskesmas are expected to be able to utilize existing funds for the sake of efficiency and productivity, not for profit.

Another department of the Health Office that is also related to the implementation of Child-Friendly Cities is the Regulation and Health Workers Section. The Regulation and Health Workers Section participates in the fulfillment of health workers and also training for health workers in the City of Depok. But dr. Rien, as the Head of the Regulations and Health Workers Section, said that the budget for training health workers was insufficient. This is because several things, such as the lack of training planning, have not yet coordinated with the Depok City Human Resources and Human Resources Development Agency (BKPSDM) and limited budget. The Head of the Regulatory Section and Health Workers know consciously that the budget will not be allocated if they do not submit training requirements for Depok City Health Office members to BKPSDM.

The lack of coordination with BKPSDM as the training organizing body made it not budgeted that some training that should have been given to health workers could not be implemented because the Regulations and Health Workers Section did not provide information to BKPSDM. Because they did not know what was needed, BKPSDM did training to health workers with a tendency to the origin, as said by Dr. Rien. The budget should be used for useful training for health workers in Depok to improve their services, notably to support Child-Friendly Cities, but the budget is useless because the training provided is not on target. Based on the explanation, it means that the training needs of the staff of the Health Office are not implemented because of the limited budget, but because the Health Office itself does not budget for training needs.

\section{b) Adequate Technology}

In this modern age, technology is something that helps facilitate various human work. Different sectors take advantage of technological sophistication to improve effectiveness and efficiency in services, including the health sector. The Depok City Health Office and the Health Department UPT make 
various kinds of innovations that are developed through technology by making different information technology-based applications. Depok City itself has a flagship program, Depok Cyber City, which is contained in the 2016 RPJM.

One of the applications that is one of the superiors of the Depok City Health Office is SIBIMA (Independent Practice Midwife Information System). The SIBIMA is an official tool for Independent Practice Midwives to record the status of checks on the health of mothers and children. The SIBIMA application is designed to display the recording and reporting of the Independent Practice Midwives in real-time (Depok.go.id). The Cyber City Depok City program is considered to be a challenge, and it turns out that it moves various SKPDs in the Depok City Government, including the Depok City Health Office, to make technology-based innovations. The Depok City Health Office makes various health-related applications, not only the SIBIMA application but other applications such as the SIMAWAS application (Mandiri Information System and Community Based Alert), SIBUGAR (Fitness Information System), SINDU (Posyandu Information System), SIMPOK Health (Information and Food Safety Reporting System). Each application link is also available on the official website of the Depok City Health Office so that the people of Depok City who need it can easily download it. The Depok City Health Office has well utilized the use of official website media or websites based on observations. Various health-related information, ranging from updated health articles, information on activities carried out by the Health Office, to information related to licensing and a list of names and addresses of all health facilities in Depok City. The technology available in the Depok City Health Office not only facilitates the Health Office staff themselves but also the community.

\section{c) Monitoring and Evaluation}

Some of the activities or programs carried out by the Depok City Health Office, both each section and UPT, have been monitored. With the monitoring carried out by the Depok City Health Office to the UPT, the Puskesmas mobilized human resources in the Puskesmas to keep or even improve services for children. Some of the existing facilities at the Cilodong Health Center must be added to enhance child-friendly services. For example, the reading corner owned by the Cilodong Health Center, where the number of books owned is minimal. Based on observations, in the reading corner of the Cilodong Health Center, it appeared that no children were reading. In the assessment component of the ChildFriendly Health Center indicator, which was previously described, it was only mentioned 'the availability of information about children's rights to health through reading corners or libraries.' Still, based on observations, it did not make children spend time waiting by reading. The lack of understanding of the material or also structuring an exciting place can be the reason for not having a single child reading in the reading corner that has been provided.

In the assessment component of the Child-Friendly Health Center indicator, it is only mentioned 'the availability of information about children's rights to health through reading corners or libraries.' Still, based on observations, it turns out that this does not make children spend time waiting by reading. The lack of understanding of the material or also structuring an exciting place can be the reason for not having a single child reading in the reading corner that has been provided.

The Family and Nutrition Health Section conducted an evaluation related to the implementation of Child-Friendly Health Centers to assess 15 indicators found in Child-Friendly Health Centers. The results of the assessment serve as the basis for making a Decree on ChildFriendly Health Centers in the coming year. Because until now, there have only been 14 Puskesmas from 35 Puskesmas in Depok, which are Child-Friendly Puskesmas, while based on Depok City Medium Term Development plan from 2006 to 2525 the number of ChildFriendly Health Centers in Depok must reach $60 \%$ or 21 Puskesmas. This means that there must be an additional 7 ChildFriendly Health Centers in Depok to be able to comply with the RPJM target. 
There is a need for an evaluation for the Health Office to consider which other the Child-Friendly Community Health Decree can prepare Puskesmas.

\section{5) Staff}

To achieve the goals of the organization, it takes people who carry out the work process, namely Human Resources. HR planning is an essential thing for an organization (Hasibuan, 2011).

The implementation of a Child-Friendly City is inseparable from the role of Human Resources both health and non-health workers to provide a service for children.

HR planning carried out by the Regulations and Health Workers Section refers to the Job Analysis and Analysis of the Workload of the Depok City Health Office and specifically for the Puskesmas UPT, referring to Minister of Health Regulation Number 75 of 2014 concerning Puskesmas. In Minister of Health Regulation Number 75 of 2014, one of which regulates the minimum amount of energy that must be owned by a health center located in urban areas, both inpatient and non-hospitalized. In its implementation, it turned out that the Puskesmas in Depok had not been able to meet HR needs planning at the Puskesmas. Health workers at the Puskesmas in Depok area are less than the minimum standards set by the Ministry of Health (Kemenkes), which is 22 staff.

Not only in the Puskesmas but in the Dinas itself, the Regulations and Health Workers section responsible for fulfilling the staff at the Health Office also felt that the energy they had was lacking. The non-implementation of the work that should be done by the Regulations and Health Workers Section is due to the absence of personnel to carry out the work. The Regulations and Health Workers Section should analyze the needs of employees submitted by the departments in the Health Office (Singal, 2017), even though this is also important to be done as an evaluation material about the workforce.

The unfulfilled employee can occur because the mechanism of procurement of staff within the Depok City Health Office is not directly carried out by the Depok City Health Office. Still, its authority is at the Ministry of Administrative Reform and Bureaucratic Reform of the Republic of Indonesia (MenPAN). The Health Office can only propose Menpan regarding the number of employees needed. However, MenPAN did not always accept the proposals that had been submitted. Unable to fulfill the energy required becomes an obstacle that must be overcome by the Health Office itself. Several methods were carried out by the Depok City Health Office to achieve the necessary human resources, such as the recruitment of non-PNS (nonGovernment Employee) and transfers from outside the region.

\section{6) Skills}

PNS or Government Employee recruitment system has been better than in the past because the recruitment system is now competency-based. For health workers, the competencies possessed are more specific. There are already regulations relating to registration signs and practice permits that must be owned by health workers as stipulated in the Republic of Indonesia Minister of Health Regulation Number 46 of 2013 concerning Registration of Health Workers. So, to provide health services, health workers are required to have documents that represent their competencies. Acceptance of CPNS (Candidates of Government Employee) with the CAT (Computer Assisted Test) system does not guarantee that the competencies possessed are by the work being carried out. Competence is the speed of a person in carrying out their duties or obligations, while through a CAT test and various qualifications do not represent the competency of an employee in carrying out his responsibilities. Requirements such as STR (Registration Certificate), which must be owned by a nurse, SIP (Practice License) that must be owned by health workers who carry out the practice. These are provisions of the Kemenkes which applies to all related professions that carry out their functions in the territory of Indonesia. Some officials who occupy structural positions should also have the competence to lead or regulate well, which should be obtained not only through a Leadership and training, but also by taking education to a higher level.

To continue their education to a higher level, the Depok City Health Office applies Tubel (Study Permit) - Ibel (Learning Task - Study Permit) to $\mathrm{HR}$ at the Health Office. In the Depok City Health Office, an employee who submits Tubel or Ibel must undoubtedly will be in the job formation that will be filled in when the education is finished. If indeed there is a guarantee that he/she will get the position after finishing his/her study, then the employee is permitted to submit Tubel or Ibel. A large allowance given to someone who occupies a specific position is directly proportional to the employee's skill level.

The Health Office does not always permit Depok City Health Office employees who wish to apply for Tubel and Ibel because they have to see in advance whether there is a need for the formation to be occupied. This is very important to do so that there is no confusion over filling the position if someone continues to pursue higher education, especially if using a government budget. 


\section{7) Shared Values}

Organizational culture greatly influences 6 (six) other elements in factors that affect organizational performance, according to McKinsey. However, the Depok City Health Office itself does not have a corporate culture set explicitly for the Depok City Health Office but uses the vision and mission of the Depok City Government, which starts from the vision and mission of the Mayor of Depok. Depok City Health Office contributes to carrying out the task in the first point, which reads "Improving the quality of Professional and Transparent Public Services."

The absence of organizational culture or values that are set can make it difficult for members of the organization to take a step or decision (Gowan et al., 2001). The vision and mission determined by the Mayor are a shared vision, and not necessarily all Regional Device Organization can comply because it is not significantly related to their respective fields. The Depok City Health Office should be allowed to form an organizational culture that is focusing in supporting the Child-Friendly initiatives.

\section{Conclusion}

The performance of the Depok City Health Office based on the target approach in measuring organizational effectiveness can be said to be going well. However, based on the data obtained, the percentage of health problems that have emerged over the past five years has tended to fluctuate. The Depok City Health Office must be consistent in carrying out its authority so that health issues, especially related to child nutrition problems, can be adequately handled. Although the percentage far exceeds the target set, cases related to child nutrition still exist in the Depok area. Therefore, the Health Office must continue to conduct monitoring and evaluation.

Seven factors influenced the Health Office to support Child-Friendly City based on McKinsey's $7 \mathrm{~s}$ model. The first factor is the strategy; the Health Office does not have a specific plan in the programs they run. Furthermore, the style factor or leadership style carried out by the Head of the Health Office or the related Section Head in general always motivates his subordinates. The third factor is the system. The Depok City Health Office has owned an excellent system, namely the availability of adequate technology, adequate budget, and a system where the Puskesmas can manage its finances. To ensure more flexibility and support the effectiveness and efficiency of services to children, as well as its monitoring and evaluation. The next factor is staff, where the Depok City Health
Office does not have enough employees because the current system does not accommodate the Health Office to provide its own-employee, and for Puskesmas that have implemented BLUDs are also constrained by their income which is not sufficient to recruit non-Government Employee. The next factor is the skill where the Health Office employees do not have competency because the training held is not yet implemented. The latter is shared values or organizational culture, where the Health Office does not have a specific organizational culture but follows the vision and mission determined by the Mayor of Depok.

Based on the results of the study, the researchers suggested the Depok City Health Office several things so that the role of the Depok City Health Office to support a Child-Friendly City can be carried out. This including a) The Health Office should facilitate the community through two-way communication, for example, through a discussion and not the presentation of one-way information from the Depok City Health Service, such as socialization. b) The Health Office should hold an internal meeting specifically to discuss the ChildFriendly City. In this meeting, coordination can be carried out periodically with all sections within the Depok City Health Office. c) It is recommended that the Health Office conduct monitoring directly to Child-Friendly Health Centers frequently or can be done without prior notice. d) It is recommended that the Depok City Health Office pay attention to training needs to support the skills of the Health Office staff. Employee skills are one of the things that determines the successful role of Depok City Health Office to support Child-Friendly Cities, especially for health workers who directly provide services to children.

\section{REFERENCES}

Bishop, K., \& Corkery, L. (2017). Designing Cities with Children and Young People. In K. Bishop \& L. Corkery (Eds.), Designing Cities with Children and Young People: Beyond Playgrounds and Skate Parks. Routledge. https://doi. org/10.4324/9781315710044

Chan, L., Erlings, E., Mizunoya, S., \& Zaw, H. (2016). A City Fit for Children: Mapping and Analysis of Child Friendly Cities Initiatives. Centre for Rights and Justice Occasional Paper Series.

Creswell, J. W. (2008). Research Design: Pendekatan Metode Kualitatif, Kuantitatif, dan Mixed. Pustaka Pelajar.

Cushing, D. F. (2016). Youth Master Plans as Potential Roadmaps to Creating Child- and Youth-friendly Cities. Planning Practice and 
Research. https://doi.org/10.1080/02697459. 2015.1110472

Dinas Kesehatan Kota Depok. (2017). Profil Kesehatan Kota Depok Tahun 2016. Dinas Kesehatan Kota Depok.

Dinas Kesehatan Kota Depok. (2018). Profil Kesehatan Kota Depok Tahun 2017. Dinas Kesehatan Kota Depok.

Febriyanti, A., \& Juwono, V. (2017). The Acceleration of Food Consumption Diversity Policy Implementation through Sustainable FoodReserved Gardening: The Case of Jakarta. Proceedings of the International Conference on Administrative Science, Policy and Governance Studies (ICAS-PGS 2017) and the International Conference on Business Administration and Policy (ICBAP 2017). https://doi.org/10.2991/ icaspgs-icbap-17.2017.14

Frieden, T. R. (2013). Government's Role in Protecting Health and Safety. New England Journal of Medicine, 368(20), 1857-1859. https://doi.org/10.1056/NEJMp1303819

Gill, T. (2019). Widening the bandwidth of childfriendly urban planning in cities. Cities \& Health, 3(1-2), 59-67. https://doi.org/10.108 $0 / 23748834.2019 .1660126$

Goldfeld, S., Villanueva, K., Tanton, R., Katz, I., Brinkman, S., Giles-Corti, B., \& Woolcock, G. (2019). Creating community indicators for early childhood development: challenges and innovations from the kids in communities study. Cities \& Health, 3(1-2), 68-77. https:// doi.org/10.1080/23748834.2019.1596525

Gowan, M., Seymour, J., Ibarreche, S., \& Lackey, C. (2001). Service quality in a public agency: same expectations but different perceptions by employees, managers, and customers. Journal ofQuality Management, 6(2), 275-291. https:// doi.org/10.1016/S1084-8568(01)00040-2

Hadi, D. U., \& Juwono, V. (2019). Implementation of a Collaborative Governance Model in Mass Rapid Transit Development in Jakarta. 33rd IBIMA Conference, 7696-7707. https://ibima. org/accepted-paper/implementation-of-acollaborative-governance-model-in-massrapid-transit-development-in-jakarta/

Hasibuan, M. S. P. (2011). Manajemen Sumber Daya Manusia. Bumi Aksara.
Kementerian Kesehatan. (2018). Buku Saku Pemantauan Status Gizi Tahun 2017.

KPP\&PA, \& BPS. (2015). Profil Anak Indonesia 2015. KPP \& PA.

Lubis, S. B. H., \& Huseini, M. (2009). Teori Organisasi: Suatu Pendekatan Makro. Departemen Ilmu Administrasi FISIP UI.

McAllister, C. (2008). Child friendly cities and land use planning: Implications for children's health. Environments, 35(3), 45-61. https://www. researchgate.net/publication/289351153_ Child_friendly_cities_and_land_use_planning_ Implications_for_children's_health

Monaghan, J. (2019). Engagement of children in developing healthy and child-friendly places in Belfast. Cities \& Health, 3(1-2), 29-39. https:// doi.org/10.1080/23748834.2018.1527175

Nam, H., \& Nam, S. I. (2018). Child-friendly city policies in the Republic of Korea. Children and Youth Services Review, 94, 545-556. https:// doi.org/10.1016/j.childyouth.2018.08.033

Riggio, E. (2002). Child friendly cities: good governance in the best interests of the child. Environment and Urbanization, 14(2), 45-58. https://doi. org/10.1177/095624780201400204

Sedletzki, V. (2011). Child Rights and Governance Roundtable: Report and Conclusions. https:// WWW.unicef-irc.org/publications/674-childrights-and-governance-roundtable-reportand-conclusions.html

Singal, A. (2017). Aspek Hukum Peran Pemerintah Melindungi Hak Anak Dalam Memperoleh Pelayanan Kesehatan. Jurnal Hukum Unsrat, 23(9), 38-52. https://ejournal.unsrat.ac.id/ index.php/jurnalhukumunsrat/article/ view/16051

UNICEF. (2017). The State of the World's Children 2017: Children in a Digital World. UNICEF. https: / / www.unicef.org/publications / index_101992.html

van Vliet, W., \& Karsten, L. (2015). Child-Friendly Cities in a Globalizing World: Different Approaches and a Typology of Children's Roles. Children, Youth and Environments, 25(2), $1 . \quad$ https://doi.org/10.7721/ chilyoutenvi.25.2.0001 